\section{Working Conditions of Nurses in the Family Health Strategy}

Lázaro Clarindo Celestino", Laura Andrian Leal ${ }^{2}$, Fernanda Ludmilla Rossi Rocha ${ }^{3}$, Silvia Helena Henriques ${ }^{4}$

\title{
Abstract
}

Background: To describe the working conditions of the nurses of the family health strategy, characterizing the forms and modalities of work contract, types of bond, working hours, benefits, career plan and salaries.

Method and Findings: Exploratory qualitative approach study participants were 18 nurses from the teams of the family health strategy of a municipality in the countryside of minas gerais. The data collection took place in july 2018 through interviews, using a script with closed questions. The ethics committee of the proposing institution according to official letter 090/2018, caae 83419418.2.0000.5393, approved the study. Two forms of work contracts have been identified represented by the city hall and outsourced companies, the latter being the mode that offers the most benefits to workers. In addition, there was a lack of commensurate links, in addition to units with physical infrastructure that were compromised, lack of basic materials and supplies essential for the provision of care, absence of essential benefits for this category, insalubrity, commission for productivity, long journeys and overload of work, neglect and devaluation of the worker.

Conclusions: This study should promote the managers' reflection on the working conditions offered to nurses in basic care, rethinking management models that help them cope with problems related to their work context, stimulating a healthy environment, mitigating possible occupational risks that could compromise physical or mental health of the worker.

\section{Introduction}

The health professional is an essential element for guaranteeing health actions and services. The working conditions to which it is subjected in a certain sector directly interfere in the effectiveness of the care

1 Nurse. Master's Degree - Program in Nursing Technology and Innovation, University of São Paulo, Ribeirão Preto College of Nursing, Ribeirão Preto, São Paulo, Brazil.

2 Nurse. PhD student of the Interunit Program of PhD in Nursing, University of São Paulo, Ribeirão Preto College of Nursing, Ribeirão Preto, São Paulo, Brazil.

3 Nurse. Professor, University of São Paulo, Ribeirão Preto College of Nursing, Department of General and Specialized Nursing, Ribeirão Preto, São Paulo, Brazil.

4 Nurse. Associate Professor at the University of São Paulo, Ribeirão Preto College of Nursing, Department of General and Specialized Nursing

\section{Contact information:}

\section{Lázaro Clarindo Celestino.}

Address: School of Nursing of Ribeirão Preto, University of São Paulo, Department of General and Specialized Nursing. Av. Bandeirantes, 3900; ZIP 14040-902, Ribeirão Preto- SP, Brazil.

Tel: +551633153440 .

”! lazaroenf@usp.br

\section{Keywords}

Work conditions; Nurses;

Family Health. 
given to the client, since its interaction with the content of the work can generate risks for self, for workers and patients with whom he or she coexists. In addition, higher-level health professionals have faced problems such as low wages, long working hours, lack of a Career Plan and Wages (PCCS), lack of continuing education policy, work overload, among others [1, 2].

In Primary Care this is no different. The Family Health Strategy (ESF), implemented in 1994 with the objective of strengthening and reorganizing basic care, made up of a multiprofessional team, according to data from the Brazilian Institute of Geography and Statistics (IBGE) since 2004, presents problems in the ESF indicated by the state managers in relation to the working conditions, such as the lack of personnel and the diversity of temporary work contracts [3]. The presence of these and other working conditions in the ESF may interfere with the assistance given to the user [4].

The term work conditions can be defined as physical structure of work (environment, noise, and illumination), physical stressors, physical, mental and labor fatigue, work accidents, among other aspects related to worker life [5]. Therefore, when dealing with these aspects, they may be related to the journey and workload, as well as types of contract and benefits of the worker, essential elements that must be taken into account when considering the quality of work for workers as a guarantee of care effective health.

In this direction, a large number of professionals in the family health strategy are still subjected to poor working conditions and precarious work links, among them the higher-level professionals who perform nuclear activities, such as doctors and nurses [6].

The nurse in the ESF scenario is an important category affected by the poor working conditions, since it stands out as the protagonist and link between the other categories of workers, carrying out multiple tasks, such as: planning and executing ac- tions in the scope of collective health, supervising direct assistance to promote health promotion, prevention, cure and rehabilitation, mediate intersectoral actions, manage health services, develop health education and lifelong education, as well as lead peers [7].

In this regard, researchers have already identified inadequate working conditions of nurses, related to excess demand, inadequate physical structure and dissatisfaction with wages and work hours, showing excessive work as an important factor of unsatisfactory work condition, which contributes to significantly increase the workloads of these professionals [8].

In agreement with these data, authors point out that these problems can be attributed to the expansion and implantation of the ESF in the country, since the labor market simultaneously passes through a process of change in the health area, based on the containment of expenses, reduction of salaries, decentralization and flexibilization in hiring staff $[9,10]$.

In this sense, through the regime of changes, this process of administrative decentralization led states and municipalities to seek other contractual possibilities for health workers. Therefore, new forms of hiring and structuring of work in the Unified Health System (SUS) were introduced, which imposed precarious working conditions on a large number of professionals, which resulted in a loss in the relationship between these individuals and the system, which hindered the quality and continuation of essential services provided to the population [11].

Therefore, it is considered that the rapid growth of health care provided by the ESF can support the inclusion of a large group of workers, often in precarious working conditions, especially the nurse, affecting their relationship with system and undermining the quality and follow-up of essential services provided to the population [11].

It is known that work in adequate conditions is essential to guarantee the effectiveness of care, but it is verified that in some health institutions, the 
reality is another distant from the adequate and, in addition, the thematic working conditions have not been studied in according to its importance for the functioning of the SUS [1, 12]. Therefore, the reality is often not known and disclosed and there is no awareness of the nurses or managers of the organizations themselves, and it is essential to describe and discuss the working conditions in which the nurses in this sphere of action have found in their daily lives.

Thus, this study presents the following questions: What are the working conditions of nurses in the Family Health Strategy? How are their employment contracts formalized?

The study should encourage nurses and managers to reflect on the actual working conditions to which ESF professionals are exposed, with a view to adopting measures or identifying strategies that promote fair and adequate forms of work with regard to links, contracts, work, benefits and others, and thus, nurse has ensured the basic conditions necessary to provide comprehensive, effective and effective care.

Thus, this study aimed to describe the working conditions of nurses in the family health strategy, characterizing the forms of work contract, types of bond, working hours, benefits, career plan and salaries assured by the municipal managers.-

\section{Method}

This is an exploratory qualitative data study. The study scenarios were 18 units of the ESF of a city in the interior of the State of Minas Gerais in Brazil. Participants in the study were nurses working in the ESF units of the above-mentioned municipality, exercising their activities for more than three months from the beginning of the data collection, since this work time should enable this professional to identify the working conditions present in his workplace.
For the collection of data, individual interviews were conducted with a closed questionnaire, with a duration of approximately 10 minutes. The form used was elaborated and validated by 5 specialist nurses and previously tested by the researcher. The questions aimed at investigating the working conditions of ESF nurses, such as: hiring modality, agency responsible for hiring, daily and weekly working hours, average monthly salary and possible benefits guaranteed by the institution as vacations, 13th salary, food stamps and meal, dental plan, transport courier, job plan, wages and careers, maternity and paternity leave, health plan, unhealthy, among others.

The data were analyzed according to thematic and inductive analysis and organized into thematic categories following three stages: pre-analysis, material exploration and treatment of the results obtained [13].

Thestudy was approved by the Research Ethics Committee (CEP) of the Proponent Institution under the protocol 090/2018, CAAE 83419418.2.0000.5393 and the participants signed the Informed Consent Form, being guaranteed their anonymity and the confidentiality of the answers.

\section{Results and Discussion}

The data revealed the predominance of the female gender in the profession, with ages ranging from 26 to 55 years old, university training time of up to two decades and dedication to the ESF at the same time. In the variable age group, the concentration of the population between 36 and 45 years old reaches 14 (78\%) in the occupation of the positions. The hegemony of women in Nursing has been a predominant reality since the beginning of the profession, because its essence comes from caring, an activity that in society was the fundamental role of women [14]. Regarding this, a study carried out by the Oswaldo Cruz Foundation (Fiocruz) in part- 
nership with the Federal Nursing Council (COFEN), emphasizes that women represent $84.6 \%$ of the workforce in this professional category, while men account for only 15\%. Despite this, there has been a growing tendency for masculinization in Nursing since the 1990s [15].

Another data observed in the study was the duration of the ESF; this variable was composed of two groups, the first presenting 12 (67\%) nurses with more than 10 years of service, and the second with $5(28 \%)$ nurses with up to 5 years.

In this respect, some evidence suggests that the exorbitant growth of registered nurses and the absence of growth in jobs and public tenders have both been a trend and a consolidation of unemployment in the profession, further aggravating the conditions of these professionals. With regard to the ESF, it is easy to understand the relatively young workforce, as it is a relatively new program that began to be implemented in 1994 and is, for the most part, the first job opportunity for these professionals [16].

In relation to professional qualification, 12 (67\%) professionals interviewed presented postgraduate studies, all of which hold a degree of specialization at lato sensu and 2 (11\%) still had masters degree (stricto sensu). At level stricto sensu, the training in Health Sciences was unanimous, in contrast to the lato sensu a diversity of specializations was observed, according to Table 1.

It is also worth noting that eight (67\%) nurses hold specialist qualifications in the areas of Family Health and Education. This number demonstrates that the professionals of the ESF have looked for specializations that help in the care of the users of this service. It is noteworthy that professionals with up to five specialization titles were found, which reinforces the non-generalizing profile of Nursing professionals that seek to meet the diversity of challenges in which the ESF fits.

It is essential that professionals seek training, since the training of health professionals is based on a historical trajectory marked by problems regarding
Table 1. Distribution of the ESF nurses, according to the level and the area of training in postgraduation. Ribeirão Preto, 2019.

\begin{tabular}{|c|c|c|c|}
\hline \multicolumn{2}{|c|}{ Characterization of training } & Nurses & Percentage \\
\hline \multicolumn{2}{|c|}{ Postgraduate level } & $N=18$ & $\%$ \\
\hline Lato sensu & Specialization & 10 & 56 \\
\hline \multirow{2}{*}{$\begin{array}{l}\text { Stricto } \\
\text { Sensu }\end{array}$} & Master's degree & 02 & 11 \\
\hline & Doctor's degree & 00 & 00 \\
\hline \multicolumn{2}{|c|}{ Specialization / Lato Sensu } & $\mathrm{N}=12$ & $\%$ \\
\hline \multicolumn{2}{|c|}{ Public health } & 02 & 17 \\
\hline \multicolumn{2}{|c|}{ Family health } & 05 & 42 \\
\hline \multicolumn{2}{|l|}{ Oncology } & 02 & 17 \\
\hline \multicolumn{2}{|l|}{ Schooling } & 03 & 25 \\
\hline \multicolumn{2}{|c|}{$\begin{array}{l}\text { Adm. Hospital and Public } \\
\text { Management }\end{array}$} & 01 & 8 \\
\hline \multicolumn{2}{|c|}{ Obstetrics/Aesthetics } & 01 & 8 \\
\hline \multicolumn{2}{|c|}{ Urgency and emergency } & 02 & 17 \\
\hline \multicolumn{2}{|c|}{ SUS management } & 01 & 8 \\
\hline \multicolumn{2}{|c|}{ Worker's health } & 01 & 8 \\
\hline \multicolumn{2}{|c|}{ Pedagogical Training in Nursing } & 01 & 8 \\
\hline \multicolumn{2}{|c|}{ Hospital administration } & 01 & 8 \\
\hline \multicolumn{2}{|c|}{ Mental health } & 02 & 17 \\
\hline \multicolumn{2}{|c|}{ Master's Degree / Stricto Sensu } & $\mathrm{N}=02$ & $\%$ \\
\hline \multicolumn{2}{|c|}{ Health Sciences } & 02 & 100 \\
\hline
\end{tabular}

the lack of capacity to deal with the health-disease process, lack of articulation between theory and practice, and dehumanization. Regarding nurses' performance in the ESF, it is believed that the specialization of primary care professionals is extremely important, since this level of care supports the goal of expanding the clinic through the development of health promotion actions involving activities of high complexity $[17,18]$.

In addition, it should be noted that 33\% of the professionals did not have post-graduate training, but despite this, the data revealed a labor context of rich opportunities for exchanges, between sys- 
tematized knowledge and the territorial experience of the ESF. These possibilities are strengthened through the diversity and level of qualification of the professionals who are post-graduates and by the genuine demands of that territory. This factor is attributed by the competency of teamwork, which is very present in the ESF, being that the work environment in team, taking into account the integrality, generates knowledge exchange, union in search of the same result, and commitment to health as a whole and, mainly, a sense of belonging to the team [19].

Regarding the working conditions of nurses, with regard to the forms of employment contract, it was observed that six (33\%) professionals had a regulated workforce in the form of a two-year work contract, extendable for the same period, and 12 (67\%) with positions held by public tender for an indefinite period and regulated by a contractual modality that requires the existence of the ESF, that is, as long as the program exists, the competition is valid. It is noteworthy that the modality of the contract labor contract was not found in the sample selected.

The modality of temporary work, with its legal fragility, is recognized by emptying working relations with the workers; in this modality are assured by law, benefits, stability and social security for the worker [2]. It should be noted that the new forms of hiring professionals deserve special attention, since they have been gradually replacing the bankrupt employees, presenting themselves as forms of precarious work through the informal ties that consist of outsourcing the work of primary care professionals, especially physicians and nurses [20].

However, even with these changes and substitutions of the forms of hiring, it is necessary to highlight the labor laws in Brazil, which were established since 1930 and on May 1, 1943, the socalled labor law consolidation (CLT) came into force. The work of nurses and other health professionals are also regulated by this legislation, in which important political, economic and social influence is observed [21].

Yet, despite the consolidation of labor laws, it is still evident in nursing the great insertion of workers through cooperatives, that is, without formal employment bonds that despite not obtaining the governmental rights and benefits, these workers face lower tax burdens [22], that did not appear in our study. In this way, it is essential the reflection of managers of the ESF for adherence to benefits, to ensure labor rights foreseen by law and incorporation of strategies that generate motivation and positive stimuli in the work for nurses, in order to guarantee effective forms of formal qualitative working conditions.

Finding in the study the modality of a two-year labor contract extendable for the same period, makes us reflect on this reality as a form of predatory contract of employment, once it is understood that at the end of this period, the labor bond of the nurse may not be renewed, generating turnover.

In this line of thought, the phenomena that lead to turnover are directly or indirectly associated with the organization, such as: benefits policy, opportunities for professional growth, supervision model, physical and environmental conditions of work, the human relationship within the organization, the personnel recruitment and selection policy, the training programs offered by human resources, the performance evaluation criteria, and the flexibility of the organization [23, 24]. Such nurses turnover has been a constant barrier in the implementation of the Family Health Strategy.

It is believed that this instability found in the ESF hurts the nurses' work process, the user service, as well as the primary elements of integrality and are against the National Primary Care Policy. Hence, the importance of fair employment contracts with nurses, which guarantee and ensure labor rights, since the main axis of the ESF values the bond of the nurse with the community where it operates. 
The working conditions of the ESF nurses may also be related to the benefits that the institution provides to the worker, evidenced in this study in three aspects, such as: general; benefits offered by the city hall (among these some provided by law and other eventual extras such as meal voucher); and offered by outsourced companies (some provided by law and other eventual extras such as meal and health insurance).

These aspects can be interpreted as a strategy of greater approximation with the data, since the variables of the benefits and contracting organs have special relevance in this research and will add triggering understandings of specific reflections on the theme, as shown in Table 2.

Upon analyzing Table 2, the benefits are presented to quantify them. Subsequently, it is possible to identify benefits similar to those found in other professional categories such as vacations, 13th salary, maternity leave, paternity leave, unhealthiness bonus, meal voucher, health insurance and transportation voucher.

The diversity and the equitable distribution of benefits are noticeable when the reality of those hired by outsourced companies is verified, where all professionals are entitled to benefit coverage, including some that do not exist for city hired contractors, such as health insurance and transportation voucher.

These data lead us to believe that, in general, working for the private sector is a guarantee of more immediate benefits. Likewise, a contract with the public authority does not mean a guarantee of stability in employment, investment in training, job and career plans or full coverage of benefits that complement the income of the health professional. However, contrary to the data found in our study, other studies affirm that outsourcing consists of a relevant way of precarious work of the nurse in the ESF, and has been gradually replacing the workforce of the insolvent employees [20].

As for the benefits offered by the city hall, it is observed that only two (8\%) of the contractors
Table 2. Distribution of nurses, according to the benefits offered in the Family Health area. Ribeirão Preto, 2018.

\begin{tabular}{|c|c|c|}
\hline \multirow{2}{*}{ Benefits } & Nurses & Percentage \\
\hline & $\mathrm{N}=18$ & $\%$ \\
\hline \multicolumn{3}{|l|}{ General benefits } \\
\hline Vacation & 18 & \multirow{4}{*}{100} \\
\hline 13th salary & 18 & \\
\hline Maternity leave & 17 & \\
\hline Paternity leave & 01 & \\
\hline Unhealthy & 17 & 94 \\
\hline Meal vouchers & 07 & 35 \\
\hline Productivity & 01 & 6 \\
\hline Health insurance & 01 & 6 \\
\hline Dental insurance & 00 & \\
\hline PMAq & 01 & 6 \\
\hline Transportation vouchers & 01 & 6 \\
\hline Salary and Career Plan & 00 & \\
\hline \multicolumn{3}{|c|}{ Benefits offered by outsourced companies } \\
\hline \multicolumn{3}{|l|}{ Vacation } \\
\hline \multicolumn{3}{|l|}{ 13th salary } \\
\hline \multicolumn{3}{|l|}{ Maternity leave } \\
\hline Unhealthy & 01 & 100 \\
\hline \multicolumn{3}{|l|}{ Meal vouchers } \\
\hline \multicolumn{3}{|l|}{ Health insurance } \\
\hline \multicolumn{3}{|l|}{ Transportation vouchers } \\
\hline \multicolumn{3}{|c|}{ Benefits offered by the city hall } \\
\hline Vacation & 17 & \multirow{4}{*}{100} \\
\hline 13th salary & 17 & \\
\hline Maternity leave & 16 & \\
\hline Paternity leave & 01 & \\
\hline Unhealthy & 16 & 84 \\
\hline Meal vouchers & 06 & 28 \\
\hline Productivity & \multirow{2}{*}{01} & \multirow[t]{2}{*}{4} \\
\hline PMAq & & \\
\hline
\end{tabular}

Source: Prepared by the authors. 
receive for productivity through the Program of Improvement of Access and Quality in Primary Care (PMAQ); even though they are in a context organized by goals to be achieved, only six (28\%) receive food stamps or food, and the most alarming of all is that the health benefit is not paid to $16 \%$ of health professionals.

In this respect, it is known that the nursing professional is one of the great workers exposed to harmful work activities, that is to say that it carries out activities detrimental to the health that can cause illnesses; so researchers have included the frequency of the subject in health organizations and attribute that the additional insalubrity is salary and non-indemnifying, whose objective is to compensate for work in conditions that are burdensome to the health of the employee [25] and is essential to the ESF nurse.

Thus, it is possible to observe the importance of the delivery of benefits to workers as a way of qualifying, instrumentalizing and effecting the assistance provided, since Article 39 of the 1988 Brazilian Federal Constitution (CFB), in turn, provides for the guarantee of benefits to the worker as a 13th salary, annual leave, maternity leave and paternal leave. In the Selective regime, Section 7 retains all the rights established in Section 39, plus others, such as: Fund for Working Time (FGTS) and Unhealthiness [26].

However, in spite of the legal decrees, it is observed that, in many cases, the requirements of the institutions are not met, and it is of the utmost importance for managers to become aware of and reflect on how their professionals can satisfactorily assist positive results for the organization itself, impacting the satisfaction and motivation of the workers, which consequently entails the reduction of costs and improvement of the care offered.

It is believed that the working conditions that the nurses are subjected to in the ESF directly impacts the care offered. In this way, it is essential to improve working conditions in order to ensure the health of workers, reducing illnesses, accidents at work and thereby increasing the resolubility of the assistance to the user of the service [2]. In this direction, managers must rethink strategies to minimize or face harmful effects of possible inappropriate work situations.

This research presents the limitation of having been performed only with nurses. Therefore, it is important to carry out other studies in order to cover other professional categories of the ESF in order to verify if there is a divergence in the perception of working conditions, as well as to rethink strategies for managing the possible factors of inadequacy of the conditions.

The research allowed the description of some inadequate working conditions that are essential to stimulate the reflection of managers and nurses in the creation of strategies to face them in the daily work.

\section{Conclusion}

The Family Health Strategy involves the performance of a team of professionals with the capacity to respond to the demands of high intellectual level and complexity, in which they pass through all the life cycles of the individual. It brings the responsibility and challenge of proposing a reorganization of the Health System in Brazil, and so it is based on several specific protocols of the Ministry of Health, besides being configured as the user's priority entrance door.

In this context, the ESF nurse performs several activities that are essential to the population, making him one of the main actors in this scenario; however, these professionals have faced inadequate working conditions, which may harm the care provided to the user, further compromising the goals and objectives of this health care strategy.

In agreement with the scientific literature this research found problems related to the working conditions of the ESF nurses: Fragile labor contracts, 
absence of essential benefits for this category, such as insalubrity and commission for productivity, long journeys and work overload, as well as neglect and devaluation of this worker.

In this context, the managers of these services have a strategic and fundamental role in the elaboration of strategies that can soften the inadequate conditions of work, often provided by management policies of people that do not respond to the needs of the workers.

Thus, there is a need to review national human resources policies, especially in Primary Care and to guarantee to ESF nurses, fair and adequate forms of work with regard to ties, contracts, workdays, benefits and others, so that, minimized the factors of risk to their own health, the nurse has assured the basic conditions necessary to provide integral care, with efficiency and effectiveness.

\section{References}

1. Maciel RHMO, Santos JBF, Rodrigues RL. Condições de trabalho dos trabalhadores da saúde: um enfoque sobre os técnicos e auxiliares de nível médio. Rev bras saúde ocup. 2015; 40(131):75-87

2. Alvarenga EC, Oliveira PTR, Pinheiro HHC, Carneiro VCCB. Condições de trabalho de equipes de saúde da família do Pará. Rev NUFEN. 2018; 10(1):58-72

3. Evangelista AP. Desprecarização do trabalho no SUS em destaque. In: A precarização das relações de trabalho no SUS prejudica a qualidade e a continuidade dos serviços prestados à população. Rede de Escolas Técnicas do SUS-RET-SUS. 2013; $32 \mathrm{p}$.

4. Monteiro C, Avelar AFM, Pedreira MLG. Interruptions of nurses' activities and patient safety: an integrative literature review. Rev Latino-Am Enfermagem. 2015; 23(1):169-79.

5. Zanelli JC, Bastos AVB, Rodrigues ACA. Campo profissional do psicólogo em organizações e no trabalho. In: Zanelli JC, Borges-Andrade JE, Bastos AVB. (Org); Psicologia, organizações e trabalho no Brasil. Porto Alegre: Artmed; 2014; 549-582.

6. Eberhardt LD, Carvalho M, Murofuse NT. Vínculos de trabalho no setor saúde: O cenário da precarização na macrorregião Oeste do Paraná. Saúde Debate. 2015; 39(104):18-29.

7. Brasil. Ministério da Saúde. Política Nacional de Atenção Básica (PNAB). Brasília, Distrito Federal: Departamento de Atenção Básica [Internet]. 2012 [cited 2019 Feb 13]. Available from: http://189.28.128.100/dab/docs/publicacoes/geral/pnab.pdf
8. Pires DEP, Machado RR, Soratto J, Scherer MA, Gonçalves ASR, Trindade LL. Nursing workloads in family health: implications for universal access. Rev Latino-Am enfermagem. 2016; 24:e2677.

9. Sarti TD, Lima RCD, Silva MZ, Maciel ELN. A institucionalização da avaliação na atenção básica: alguns aspectos para a construção de práticas democráticas no contexto da estratégia saúde da família. UFES Rev odont. 2008; 10(1):63-69.

10. Pinto LF, Giovanella L. Do Programa à Estratégia Saúde da Família: expansão do acesso e redução das internações por condições sensíveis à atenção básica (ICSAB). Ciênc saúde coletiva. 2018; 23(6):1903-1914.

11. Flegele DS, Guerra MA, Espindula KD, Lima RCD. Trabalhadores de saúde e os dilemas das relações de trabalho na estratégia saúde da família. Revista Brasileira de Pesquisa em Saúde. 2010; 12(2):5-11.

12. Vieira M, Chinelli F. Relação contemporânea entre trabalho, qualificação e reconhecimento: repercussões sobre os trabalhadores técnicos do SUS. Ciênc saúde coletiva. 2013; 18(6):1591-1600.

13. Braun V, Clarke V. Using thematic analysis in psychology. Qual Es Psychol. 2006; 3(2):77-101.

14. Araujo ST, Penaforte KL. Psychosocial risks related to work: perception of nursing professionals. J Nurse UFPE on line [Internet]. 2016 [cited 2018 Dec 12]; 10(11):3831-9. Available from: https://periodicos.ufpe.br/revistas/revistaenfermagem/ article/view/11463/13297

15. Agência Fiocruz de Notícias. Pesquisa inédita traça perfil da enfermagem no Brasil. Rio de Janeiro, São Paulo [Internet]. 2015 [cited 2018 Dec 12]. Available from: https://portal.fiocruz.br/ noticia/pesquisa-inedita-traca-perfil-da-enfermagem-no-brasil Acesso em: 10 set. 2018.

16. Oliveira JSA, Pires DEP, Alvarez AM, Sena RR, Medeiros SM, Andrade SR. Trends in the job market of nurses in the view of managers. Rev Bras Enferm. 2018; 71(1):148-55.

17. Gomes AP, Costa JRB, Junqueira TS, Arcuri MB, Siqueira-Batista R. Atenção primária à saúde e formação médica: entre episteme e práxis. Rev bras educ med. 2012; 36(4):541-9.

18. Oliveira MPR, Menezes IHCF, Sousa LM, Peixoto MRG. Formação e Qualificação de Profissionais de Saúde: Fatores Associados à Qualidade da Atenção Primária. Rev bras educ med. 2016;40(4):547-559.

19. Peruzzo HE, Bega AG, Lopes APAT, Haddad MCFL, Peres AM, Marcon SS. The challenges of teamwork in the family health strategy. Esc. Anna Nery [Internet]. 2018 [cited 2019 May 06]; 22(4):e20170372. Available from: http://www.scielo.br/pdf/ean/ v22n4/1414-8145-ean-22-04-e20170372.pdf

20. Cavalcante MVS, Lima TCS. A precarização do trabalho na atenção básica em saúde: relato de experiência. Argumentum. 2013; 5(1):235-256 
21. Freitas GF, Fugulin FMT, Fernandes MFP. A regulação das relações de trabalho e o gerenciamento de recursos humanos em enfermagem. Rev esc enferm USP. 2006; 40(3):434-38.

22. Trochin DMR, Fugulim FMT, Peres HHC, Massorello MCKB, Fernandes MFP, Ciampone MHT, et al. Gerenciamento em enfermagem (Paulina Kurcgant coord). 2th ed. Rio de Janeiro: Guanabara Koogan; 2010

23. Medeiros CRG, Junqueira AGW, Schwuingel G, Careno I, Jungles LAP, Saldanha OMFL. A rotatividade de enfermeiros e médicos: um impasse na implementação da Estratégia de Saúde da Família. Ciênc saúde coletiva. 2010; 15(suppl.1):1521-31.

24. Tonelli B, Leal AP, Tonelli W, Veloso DC, Gonçalves D, Tonelli S. Rotatividade de profissionais da Estratégia Saúde da Família no município de Montes Claros, Minas Gerais, Brasil. RFO [Internet]. 2018 [cited 2018 Dec 12]; 23(2). Available from: http://www. seer.upf.br/index.php/rfo/article/view/8314

25. Silva DN, Pires CRF. Insalubridade em atividades laborais realizadas pela equipe de enfermagem. Amazonia: Science and health [Internet]. 2017 [cited 2018 Dec 12]; 5(1):40-47. Available from: http://186.192.241.211/index.php/2/article/view/1024/pdf

26. Brasil. Ministério da Saúde. Secretaria de Gestão do trabalho e da Educação na Saúde. Departamento de Gestão e da Regulação do Trabalho em Saúde. Programa Nacional de Desprecarização do Trabalho no SUS: Desprecariza SUS: perguntas \& respostas. Comitê Nacional Interinstitucional de Desprecarização do trabalho no SUS. Brasília, DF; 2006.

Publish in International Archives of Medicine

International Archives of Medicine is an open access journal publishing articles encompassing all aspects of medical science and clinical practice. IAM is considered a megajournal with independent sections on all areas of medicine. IAM is a really international journal with authors and board members from all around the world. The journal is widely indexed and classified Q2 in category Medicine. 